\title{
ANALISIS FAKTOR - FAKTOR YANG MEMPENGARUHI PENDAMPINGAN PERSALINAN DI PUSKESMAS KARANG REJO KOTA TARAKAN
}

\author{
Ratnanengsih \\ Jurusan Kebidanan FIKES Universitas Borneo Tarakan \\ *Email: malika_noya@yahoo.com
}

\begin{abstract}
Abstrak
Kehamilan dan persalinan merupakan proses yang fisiologis, pada kenyataannya masih banyak persalinan dengan patologi, agar tidak mengarah pada hal yang patologis maka diperlukan pendampingan persalinan. Seorang pendamping harus mempersiapkan mental untuk menyiapkan suasana yang menyenangkan bagi ibu bersalin. Pendampingan persalinan bermanfaat bagi psikologis dan kelancaran persalinan ibu. Tujuan Penelitian ini adalah untuk menganalisis faktor-faktor yang mempengaruhi pendampingan persalinan. Desain Penelitian ini menggunakan metode survey analitik cross sectional, pengambilan sampel dilakukan dengan teknik accidental sampling, sampel yang digunakan berjumlah 36 responden, dianalisis menggunakan uji korelasi chi square dengan kemaknaan $\alpha=0,05$ menggunakan SPSS. Hasil penelitian yaitu faktor karakteristik jumlah anak yang dimiliki (p 0,067), faktor ekonomi (p 0,254), faktor pengetahuan (p 0,001), maka $\rho<\alpha$ maka $\mathrm{H} 0$ ditolak artinya ada faktor pengaruh dalam pendampingan suami pada proses persalinan, yaitu pengetahuan.
\end{abstract}

Kata kunci : Faktor, pendampingan persalinan

\begin{abstract}
Analysis of Factors Affecting Childbirth Assistance at Karang Rejo Health Center, Tarakan City. Pregnancy and childbirth are physiological processes, in fact there are still many childbirth with pathology, so as not to lead to pathological things, it is necessary to provide maternity assistance. A companion should prepare mentally to prepare a pleasant atmosphere for the maternity mother. Maternity assistance is beneficial for the psychological and smooth delivery of the mother. The purpose of this study is to analyze the factors that affect childbirth assistance. The design of this study using cross sectional analytical survey method, sampling was done by accidental sampling technique, sample used by 36 respondents, analyzed using chi square correlation test with $\alpha=0.05$ using SPSS. The results of the study are characteristic factors of the number of children owned ( $p$ 0.067), economic factors ( $p$ 0.254), knowledge factors ( $p 0.001)$, then $\rho<\alpha$ then $\mathrm{HO}$ rejected means there is an influence factor in the mentoring of husbands in the process of childbirth, namely knowledge.
\end{abstract}

Keywords:factor, delivery assistance 


\section{Pendahuluan}

Kehamilan dan persalinan merupakan hal yang fisiologis, namun setiap wanita memiliki respon yang berbeda-beda terhadap penerimaan kehamilan dan proses persalinan. Proses persalinan fisiologis akan terjadi bila dilatasi/pembukaan serviks dan menyebabkan rasa nyeri pada ibu dan kepala janin mengalami penurunan. Kondisi ini akan menyebabkan stress dan cemas pada ibu dan akan berdampak pada kesejahteraan janin dan psikologis ibu (Lowdwermilk, 2013).Komplikasi persalinan merupakan keadaan yang terjadi pada masa persalinan dapat mengancam jiwa ibu atau janin akibat (langsung) dari persalinan. Komplikasi persalinan terdiri dari persalinan macet, rupture uteri, infeksi atau sepsis, perdarahan, ketuban pecah dini (KPD), malpresentasi atau malposisi janin, preeclampsia dan eklampsia.

Penurunan angka kejadian komplikasi persalinan diperlukan peran serta keluarga (terutama suami), hal ini sejalan dengan kebijakan dan strategi pemerintah dalam rangka menurunkan angka kejadian komplikasi persalinan di Indonesia melalui program MPS (Making Pregnancy Safer). Hasil yang diharapkan dari strategi tersebut adalah meningkatkan peran aktif keluarga selama kehamilan dan persalinan (Depkes, 2014).
Kelancaran proses persalinan dapat dilihat dari lamanya proses persalinan berlangsung serta tidak mengalami hambatan dan komplikasi saat persalinan. Pada kenyataannya, masih banyak ibu bersalin yang mengalami ketidaklancaran proses persalinan yakni melewati garis waspada pada lembar observasi partograf. Hal ini dikarenakan banyak ibu bersalin yang mengalami ketakutan dan kecemasan yang berlebih sehingga mengganggu kontraksi yang dapat menghambat proses persalinan.

Faktor-faktor yang mempengaruhi kelancaran proses persalinan diantaranya adalah power (his, tenaga meneran), passage, passenger (janin, plasenta), psikis (salah satunya dipengaruhi oleh pendamping persalinan), posisi, tempat persalinan, dan penolong. Seorang ibu yang memasuki masa persalinan akan muncul perasaan takut, khawatir, ataupun cemas. Ketakutan yang sering dirasakan oleh ibu yang melahirkan, disebabkan oleh ketakutan dengan kondisi janinnya dan ketakutan akan rasa sakit.

Setiap persalinan selalu memerlukan pengawasan sehingga pertolongan yang tepat dapat diberikan. Kehadiran seorang pendamping persalinan selama proses persalinan akan membawa dampak yang baik, karena dapat memberikan rasa nyaman, aman. 
Semangat serta dukungan emosional yang dapat membesarkan hati, mengurangi rasa sakit dan mempercepat proses persalinan (Latipun, 2010). Persalinan yang tidak didampingi akan menimbulkan dampak perasaan takut yang dapat menimbulkan ketegangan sehingga menyebabkan gangguan his, dan akhirnya persalinan berjalan tidak lancar. Pendamping persalinan memegang peranan penting dalam proses kelahiran.

World health organization (WHO) telah merekomendasikan bahwa pendamping persalinan adalah atas pilihan ibu sendiri. Namun saat ini partisipasi pria dalam kesehatan reproduksi masih rendah, masih banyak suami belum mampu menunjukkan dukungan penuh terhadap proses persalinan, terdapat $68 \%$ persalinan di Indonesia tidak didampingi suami selama proses persalinan.(Rizki, Dian 2016) .

Kebijakan di tempat bersalin mengijinkan suami atau anggota keluarga lainnya menemani ibu waktu bersalin. Bidan harus selalu mengingatkan dari awal pada suami, bahwa pendampingan suami akan berpengaruh pada proses persalinan istrinya. Bidan juga memberikan pengarahan bahwasanya, seorang ibu hamil pasti akan mengalami ketakutan tersendiri menjelang proses persalinan, dan jika pada saat persalinan ada pendamping sudah bisa dipastikan ibu akan merasa tenang, aman dan nyaman karena ada suami yang mendampinginya.

Efek dari tidak adanya pendampingan suami selama persalinan berdampak kecemasan pada ibu mengakibatkan kadar katekolamin yang berlebihan sehingga menyebabkan turunnya aliran darah ke rahim, kontraksi rahim lemah, turunnya aliran darah ke plasenta, oksigen yang tersedia untuk janin berkurang serta dapat meningkatkan lamanya persalinan.

Beberapa penelitian juga menunjukkan bahwa ada hubungan antara pendampingan suami dengan kelancaran proses persalinan, Persalinan tanpa pendamping akan menambah resiko terjadinya persalinan tidak lancar, adanya hubungan pendampingan suami dengan pengurangan rasa nyeri pada persalinan kala 1 fase aktif. Oleh karena itu, pendampingan persalinan sangat penting dalam proses persalinan. Pendampingan persalinan yang dilakukan oleh suami, dapat dipengaruhi beberapa faktor, maka peneliti akan meneliti faktor apa saja yang mempengaruhi pendampingan persalinan dan faktor mana yang paling berpengaruh. Hal ini akan dilakukan di puskesmas, karena puskesmas merupakan salah satu pelayanan pertama persalinan yang dianjurkan pemerintah selama pandemic ini. 
Puskesmas Karang Rejo merupakan salah satu puskesmas yang sudah terakreditasi utama dengan pelayanan yang cukup lengkap diantaranya melayani persalinan 24 jam, data puskesmas Karang Rejo mempunyai pasien bersalin dengan jumlah melampaui target yaitu nyak 100,2\%. Berdasarkan studi pendahuluan yang dilakukan di Puskesmas Karang Rejo, ditemui $6 \mathrm{ibu}$ hamil trimester 2 dan 3, 5 diantaranya menyatakan jika bersalin akan didampingi oleh suami, dan satu menyatakan akan didampingi ibunya, oleh karena itu, peneliti tertarik untuk meneliti di Puskesmas Karang Rejo.

\section{Metode}

Desain penelitian yang digunakan dalam penelitian ini adalah survey analitik. dan metode penelitian yang digunakan dalam penelitian ini adalah Survei Cross Sectional. Sumber data yang digunakan adalah data sekunder, dengan teknik pengumpulan data melalui kuesioner. Populasi yang digunakan adalah seluruh ibu bersalin yang ada pada saat penelitian, dengan menggunakan metode total sampling dan accidental sampling, disesuaikan dengan jumlah responden yang ada pada saat penelitian yang berjumlah 36 responden. Tempat penelitian yang digunakan adalah Puskesmas Karang Rejo Kota Tarakan. Penelitian dilakukan bulan Agustus - Oktober 2020. Dalam analisis data pada penelitian ini menggunakan uji signifikansi yang bertujuan untuk mengetahui keeratan hubungan antara variabel digunakan uji korelasi chi square dengan kemaknaan $\alpha=0,05$, kemudian dianalisis dengan bantuan perhitungan komputer SPSS for windows. Bila didapatkan $\rho<\alpha$ maka H0 ditolak artinya ada faktor pengaruh dalam pendampingan suami pada proses persalinan.

\section{Hasil}

Berdasarkan penelitian yang dilakukan oleh peneliti dengan jumlah sample 36 responden, maka didapatkan hasil penelitian mengenai analasis faktor-faktor yang mempengaruhi pendampingan persalinan sebagai berikut : karakteristik pendamping persalinan,faktor ekonomi dan pengetahuan pendamping persalinan. 
Tabel 1 Distribusi Frekuensi Karakteristik Pendamping Persalinan

\begin{tabular}{|c|c|c|c|}
\hline Karakteristik & $\begin{array}{c}\text { Jumlah } \\
\text { (n) }\end{array}$ & $\begin{array}{c}\text { Persentase } \\
(\%)\end{array}$ & $P$ value \\
\hline \multicolumn{4}{|c|}{ Pendamping Persalinan } \\
\hline Suami & 36 & 100 & 0,741 \\
\hline Ibu Kandung & 0 & 0 & \\
\hline Keluarga & 0 & 0 & \\
\hline \multicolumn{4}{|c|}{ Pendidikan Terakhir } \\
\hline SD & 7 & 19,4 & \\
\hline SMP & 8 & 22,2 & 0,515 \\
\hline SMA & 21 & 58,4 & \\
\hline PT & 0 & 0 & \\
\hline \multicolumn{4}{|c|}{ Status Pekerjaan Pendamping } \\
\hline Bekerja & 36 & 100 & 0,267 \\
\hline Tidak Bekerja & 0 & 0 & \\
\hline \multicolumn{4}{|c|}{ Jumlah Anak Yang dimiliki } \\
\hline 1 & 6 & 16,7 & 0,067 \\
\hline $2-3$ & 23 & 63,9 & \\
\hline$>4$ & 7 & 19,4 & \\
\hline \multicolumn{4}{|c|}{ Umur Pendamping } \\
\hline $18-24$ th & 5 & 13,9 & 0,555 \\
\hline $25-31$ th & 20 & 55,6 & \\
\hline $32-38$ th & 7 & 19,4 & \\
\hline$>39$ th & 4 & 11,1 & \\
\hline
\end{tabular}

Berdasarkan tabel 1 didapatkan hasil seluruh proses pendampingan persalinan dilakukan oleh suami (100\%), pendidikan terakhir pendamping persalinan sebagian besar berpendidikan SMA $(58,4 \%)$, Seluruh pendamping persalinan bekerja (100\%), dan jumlah anak yang dimiliki sebagian besar berjumlah 2-3 anak $(63,9 \%)$, pendamping persalinan sebagian besar berumur 25-31 tahun $(55,6 \%)$.

Tabel 2. Faktor Ekonomi pendamping persalinan

\begin{tabular}{cccc}
\hline $\begin{array}{c}\text { Penghasilan Pendamping } \\
\text { Persalinan }\end{array}$ & $\begin{array}{c}\text { Jumlah } \\
(\mathbf{n})\end{array}$ & $\begin{array}{c}\text { Persentase } \\
(\boldsymbol{\%})\end{array}$ & P value \\
\hline Rp. 500.000 - Rp. 1.500 .000 & 21 & 58,3 & \\
Rp. $1.500 .050-$ Rp. 2.500 .000 & 9 & 25 & 0,254 \\
Rp. 2.500.050 - Rp. 3.500 .000 & 4 & 11,1 & \\
>Rp. 3.500 .050 & 2 & 5,6 & \\
\hline
\end{tabular}

Berdasarkan tabel 2 diatas diketahui bahwa sebagian besar responden berpenghasilan $\mathrm{Rp}$. 500.000 - Rp. 1.500 .000 sebanyak 58,3\%. 
Tabel 3 Faktor Pengetahuan Pendamping Persalinan

\begin{tabular}{cccc}
\hline Pengetahuan & $\begin{array}{c}\text { Jumlah } \\
(\mathbf{n})\end{array}$ & $\begin{array}{c}\text { Persentase } \\
(\boldsymbol{\%})\end{array}$ & P value \\
\hline Baik & 19 & 52,8 & \\
Cukup & 16 & 44,4 & 0,001 \\
Kurang & 1 & 2,8 & \\
\hline
\end{tabular}

Berdasarkan tabel hasil penelitian diatas diperoleh hasil bahwa pengetahuan

\section{Pembahasan}

Pendampingan persalinan yang dilakukan oleh suami adalah pendampingan yang benar karena pendampingan oleh suami memberikan efek yang sangat besar bagi ibu bersalin, terutama pada kelancaran persalinan, mengurangi nyeri persalinan dan juga memberikan psikologis positif bagi ibu dalam menghadapi proses persalinan.(Salehi et al, 2016)

Pendidikan pendamping persalinan akan mempunyai efek bagi ibu bersalin terutama untuk pengetahuannya, Individu yang berpendidikan akan mempunyai pengetahuan tentang pentingnya pendampingan pada saat persalinan dan mereka cenderung melakukan pendampingan pada saat persalinan, sebaliknya individu yang tidak berpendidikan pengetahuannya akan kurang dan mereka cenderung tidak melakukan pendampingan saat persalinan.(Sri dkk, 2017).

Seluruh pendamping persalinan bekerja walaupun dengan berbagai variasi jumlah pendamping persalinan sebagian besar berpengetahuan baik $(52,8 \%)$. penghasilan. Keadaan sosial ekonomi keluarga akan mempengaruhi proses pendampingan suami ketika istri melahirkan, suami yang mempunyai tingkat sosial ekonomi yang mapan dengan pekerjaan yang relevan akan lebih cenderung memperhatikan dan mendampingi istrinya pada saat melahirkan, hal ini berbeda dengan suami yang mempunyai status sosial ekonomi yang kurang mampu, suami lebih cenderung untuk kurang memperhatikan istri pada saat bersalin, suami lebih sibuk untuk mencari biaya persiapan persalinan bagi istrinya.

Suami yang mempunyai usia matang (dewasa) akan berusaha semaksimal mungkin memberikan dukungan pendampingan pada saat istrinya melahirkan, hal ini dikarenakan kematangan usia untuk berusaha mengerti tentang psikologis istri pada saat persalinan begitu pula dengan pengalaman dari banyaknya jumlah anak yang dimiliki sehingga pendamping persalinan khususnya 
suami mempunyai pengalaman pendampingan sesuai dengan jumlah anak yang dimilikinya.

Berdasarkan tabel hasil penelitian diatas diperoleh hasil bahwa pengetahuan pendamping persalinan sebagian besar berpengetahuan baik (52,8\%). Pengetahuan individu akan mempengaruhi pelaksanaan pendampingan suami terhadap istri pada saat melahirkan, suami yang mempunyai pengetahuan yang baik akan berusaha semaksimal mungkin memberikan dukungan pendampingan pada saat istrinya melahirkan, hal ini dikarenakan dukungan pendampingan akan memberikan motivasi yang besar kepada istri pada saat melahirkan, begitu pula sebaliknya suami yang mempunyai pengetahuan yang kurang, biasanya tidak mendampingi pada saat istrinya melahirkan, hal ini dikarenakan ketidaktahuan akan manfaat pendampingan suami terhadap istri pada saat melahirkan.

Berdasarkan hasil uji statistik dengan menggunakan uji chi square diperoleh nilai $\mathrm{p}=$ $0,001 \quad(\mathrm{p}<0,05)$ yang menunjukkan ada hubungan antara pengetahuan terhadap pendampingan persalinan, yang artinya $\mathrm{Ha}$ diterima dan Ho ditolak. Adanya pengaruh antara pengetahuan dalam pendampingan persalinan, dikarenakan pengetahuan yang baik dari responden dapat mempengaruhi dalam pendampingan persalinan.
Pengetahuan suami adalah sebagai salah satu faktor yang mempermudah (predisposing factor) terhadap terjadinya perubahan perilaku khususnya dalam pendampingan persalinan. Hal ini sesuai dengan pendapatan L.Green dalam buku Soekidjo Notoatmodjo (2003) yang menyatakan bahwa salah satu faktor penentu terjadinya perubahan perilaku adalah adanya faktor pemudah (predisposing factor) yang di dalamnya termasuk tingkat pengetahuan.

Pengetahuan selain dari informasi dapat juga diperoleh dari pengalaman seseorang yang pernah terjadi pada masa lalu atau pada masa sekarang. Pengalaman adalah guru terbaik yang merupakan sumber pengetahuan dan informasi yang dapat dipahami dan dimengerti oleh individu itu sendiri dari proses belajar yang sudah dilakukanya. Informasi juga dapat mempengaruhi pengetahuan suami tentang pendampingan persalinan. Pada zaman modern ini informasi dapat diperoleh dari berbagai media, misalnya media cetak maupun elektronik.(Komala, Aniroh 2014)

\section{Kesimpulan}

Faktor Karakteristik yang berpengaruh dalam pendampingan persalinan yaitu jumlah anak yang dimiliki ( $\mathrm{P}>0,05)$, Faktor ekonomi tidak berpengaruh terhadap pendampingan persalinan $(\mathrm{P}>0,05)$, Faktor Pengetahuan berpengaruh terhadap pendampingan 
persalinan $(\mathrm{P}<0,05)$. Berdasarkan hasil korelasi chi square dengan kemaknaan $\alpha$ $=0,05$, didapatkan $\rho<\alpha$ maka H0 ditolak artinya ada faktor pengaruh dalam pendampingan suami pada proses persalinan, yaitu pengetahuan. Sebagai saran diharapkan bagi suami sebagai orang terdekat dengan istri untuk berperan aktif mendampingi dalam proses persalinan agar lebih dapat menambah kepedulian serta juga wawasan pengetahuan tentang proses persalinan dan hal-hal apa saja yang dibutuhkan istri selama proses persalinan, bagi tenaga kesehatan terutama bidan untuk dapat meningkatkan program tentang KIE pengetahuan, sikap dan dukungan pendamping persalinan pada proses persalinan.

\section{Referensi}

Barrett,S J, StarkAnn. 2010. Factors Associated With Labor Suppor Behaviors of Nurses. The Journal of Perinatal Education, 19(1), 12-18, doi: $10.1624 / 105812410 X 481528$

Cook Katie, Loomis. 2012. The Impact of Choice and Control on Women's Childbirth Experiences. The Journal of Perinatal EducationVolume 21, Number 3

Depkes RI. 2014. Catatan tentang Perkembangan dalam Praktek

Kebidanan. Jakarta : Depkes RI. Indrayani, Djami. 2013. Asuhan Persalinan dan Bayi Baru Lahir. Jakarta : TIM.

Haryanto Budi. 2014. Hubungan Pendampingan Persalinan Dengan
Tingkat Kecemasan.Keperawatan Universitas Muhammadiyah Purwokerto Hodnett, Gates, Hofmeyr, Carol Sakala.2014.Continuous support for women during childbirth.. PMC Journal Kartikasari, Hernawily, Halim.Hubungan Pendampingan Keluarga Dengan Tingkat Kecemasan Ibu Primigravida Dalam Menghadapi Proses Persalinan Jurnal Keperawatan, Volume XI, No. 2, Oktober 2015

Komala, N. M. R. and Aniroh, U. (2014). Hubungan Pengetahuan Terhadap Perilaku Suami Dalam Melakukan Pendampingan Pada Persalinan Kala I Fase Aktif Di Bidan Praktek Mandiri Wilayah Kerja Puskesmas Bergas Kabupaten Semarang. pp. 137-143. Prosiding Seminar Nasional LPPM Universitas Muhammadiyah Semarang.

Latipun. 2010. Psikologi Konseling. website : www.cdc.gov/pendampingpersalinan/training/glossary diakses pada tanggal 16 April 2020

Lowdermilk, dkk. 2013. Keperawatan Maternitas edisi 8 buku 1. Jakarta : Salemba Medika.

Manuaba, Ida Gede Bagus. 2010. Ilmu Kebidanan Penyakit Kandungan Dan Keluarga Berencana Untuk Pendidikan Bidan, Jakarta: EGC .

Michelle \& Murray. 2013. Persalinan \& Melahirkan. Jakarta: EGC. Halaman 363

Notoatmodjo, Soekidjo. 2012. Metodologi Penelitian Kesehatan. Jakarta: Rineka Cipta.

POGI, dkk. Buku Acuan Pelatihan Klinik Asuhan Persalinan Normal. Jakarta : JNPK-KR Departemen Kesehatan Republik Indonesia. 2008

Rizky Eka Noviana, Dian Puspitasari.2016. Kesiapan Suami Sebagai Pendamping 
Persalinan Di Puskesmas Pleret

Kabupaten Bantul Yogyakarta. Media Ilmu Kesehatan Vol. 5, No. 1, April 2016.

Romano, Lothian.2018. Promoting, Protecting, and Supporting Normal Birth: A Look at the Evidence.JOGNN Vol. 37, Issue 1

Saifudin, Abdul bari.Buku Acuan Nasional Pelayanan Kesehatan Maternal Dan Neonatal Edisi 1 Cetakan 4. Jakarta: YBPSP. $2011: 89$ - 91, 122 - 139

Salehi A, Fahami F, Beigi M. The effect of presence of trained husbands beside their wives during childbirth on women's anxiety. Iran $J$ Nurs Midwifery Res. 2016;21(6):611-615. doi:10.4103/17359066.197672

Siti Khotimah, Evin Noviana Sari. 2018. Analisis Perbedaan Partisipasi Suami Dan Tenaga Kesehatan Terhadap Tingkat Kecemasan Ibu Intrapartum Primipara. Journal For Quality In Women's Health Vol. 1 No. 2 September 2018.
Sulistyawati, Ari. 2010. Asuhan Kebidanan Pada Ibu Bersalin. Jakarta : Salemba Medika

Sumarah, dkk. Perawatan Ibu Bersalin. Cetakan 5. Yogyakarta : Fitramaya. 2010 : $2-4,179$

Sumiati. Pengaruh Peran Pendampingan Suami Terhadap Percepatan Proses Persalinan Kala I Fase Aktif Di BPS Kisworo Surabaya, 2014. Embrio, Jurnal Kebidanan Vol. V ,Maret 2015

Sri Rahayu Ningsih, Sabarinah, and Iwan Ariawan, 2017,Determinants of Birth Delivery Assistance in Six IndonesianProvinces, 2012 in The 1st International Conference on Global Health, KnE Life Sciences, pages 28-38.

Wati, Saras Arum Tini. Hubungan Pendampingan Suami Dengan Intensitas Nyeri Persalinan Kala I Di RS PKU Muhammadiyah Yogyakarta, 2010. Jurnal kebidanan, Arum Tini Saras Wati, PKU Muhammadiyah yogyakarta.

WHO. 2013. Integrated Management of Pregnancy and Childbirth (IMPAC). Maternal, Newborn, Child and Adolescent Health.. 